\title{
Ecological Impact behind Mega Project Development
}

\author{
K. Swangjang
}

\begin{abstract}
In Thailand, one of Southeast Asia countries, agricultural area can be normally found, however, farmlands have been traditionally developed depending on economic benefits. These are likely to cause a variety of mechanisms interacting to habitat change in these areas which bring to the aim of this study. That is to investigate the effect of land use change to ecological factor with focus on bird communities. The study was separated into two parts, including land use analysis and bird species investigation. The suburbs area connected to Suvarnabhumi Airport was selected. From GIS layer evaluation, there were statistical association of the change between the year 1994 and 2002, with significant difference $(P<0.01)$, evaluated by correlation coefficient. For bird species communities, the species disappearance was found from three to thirty-three species depending on the pattern of land use development. The disappearance of species which use paddy fields as their habitats showed significant relationship $(P<0.05)$, evaluated by pearson correlation.
\end{abstract}

Index Terms-Ecological impact, bird index, land use, Suvarnabhumi Airport, Thailand.

\section{INTRODUCTION}

Contribution of proposed projects may affect some hidden impacts, resulting from the change of ecological patterns. Although land use and ecological characteristics are continually changed at different temporal scales, project development may stimulate those changed by increasing or decreasing habitat heterogeneity in a landscape. Landuse intensification influences regional biota in several ways [1]. From the study of Sirami et al. (2008), initial landscape compositions affect the change of species occurrence [2].

The recognition of closed relation between landscape and habitat is confirmed by the numerous studies of many experts in different regions. The study to incorporating biodiversity based objectives into planning decision in New South Wales, Australia [3]. Rossi et al. (2008) used ecological indicators to evaluate habitats and integrated into the guidance for landscape management in Italy [4]. Opdam et al. (2006) developed ecological indicators as a tool to measures how ecological sustainability is incorporated in landscape plans in the Netherlands [5]. Nejadi et al. (2012) introduced model of land use change on wild life habitat in Lisar protected area, Iran [6]. This study insisted that the achievement of ecological sustainability heavily depends on the persistence of species within its ecosystem.

Manuscript received July 25, 2014; revised November 21, 2014. This work was supported by Office of the Commission for Higher Education and Thailand Research Fund under Grant RMU5080004, together with Faculty of Science, Silpakorn University.

K. Swangjang is with the Department of Environmental Science, Faculty of Science, Silpakorn University, Nakorn Pathom 73000 Thailand (e-mail: knokporn@su.ac.th).
Habitat change has long been interested. Indicators taxa have useful because geographical scales require for decision planning [7]. The use of bird as ecological indicator has been studied by many experts. Comparing with other animal groups, birds are more easily observed and useful indicators for land use change

In Thailand, paddy field is the main agricultural crop; however, it is dramatically decreased in the last three decades. In turn, fish farm is gradually increased and replaced by the paddy field, especially in the central plain which the topography and environmental factors are suitable for both fields. These shifting have been mainly caused by economic benefits.

This research aims to investigate ecological impact, with focusing on bird communities, resulting from mega project development. Suvarnabhumi Airport, the Asian International Airport, was considered as mega project introduced in the country area which cause the rapid changed of land use around the areas connected to the airport. Since it began to develop in 1996, the rapid changed of land use to support this mega project has been recognized. Significantly, this area is known as the major receiving water, the natural barrier, at the east part of Bangkok.

Besides the shift to urban area, some unseen change is within the agricultural part. The decreasing of paddy fields has been reversed by fish farms since the year 1970 as shown in Table I [8]. It was found that the area of fish farms was increased by $33 \%$ whereas paddy fields were decreased by significant rate at $63 \%$ from the year 1971 to 2007 . The major shift was happen during the period of 2000-2007 which was the same duration of airport development. The change of habitat types was our interest to consider the other effects of related ecological structure.

TABLE I: FISH FARM AND PADDY FIELD DURING 1971-2007
\begin{tabular}{|l|c|l|}
\hline Years & $\begin{array}{c}\text { Fish-farm } \\
\text { (percentage) }\end{array}$ & $\begin{array}{l}\text { Paddy-field } \\
\text { (percentage) }\end{array}$ \\
\hline 1971 & 12.51 & 68.16 \\
\hline 1980 & 38.59 & 33.40 \\
\hline 1982 & 33.59 & 39.45 \\
\hline 1988 & 46.70 & 22.78 \\
\hline 2000 & 24.54 & 35.82 \\
\hline 2007 & 45.13 & 5.04 \\
\hline
\end{tabular}

Source: Department of Land Development, Thailand, 2014

According to Thailand's hierarchical administrative system, the levels from the lowest to the highest are Tumbon or Subdistrict, Amphoe or district and Province, respectively. It is important to scope the study area according to those official units since the data used in this study, including land use GIS theme and target population, are separated in each administrative unit. Two districts, namely Bangpli and Bangsaothong, located in Samutprakarn province are 
selected depending on the area connected to the airport. Within these districts, nine subdistricts are included. These are Bangpliyai, Bangkaew, Bangpla, Rachatewa, Nongpru, Bangchahlong in Bangpli and Bangsaothong, Srisajorakhenoi, Srisajorakheyai in Bangsaothong (Fig. 1).

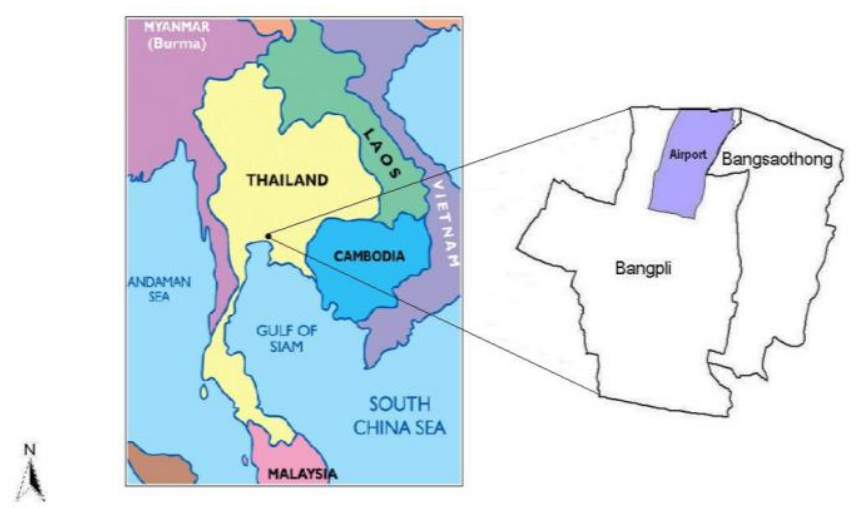

Fig. 1. Study area.

\section{PROCEDURE}

\section{A. Land Use Analysis}

Data preparation, input, subsequent map operations, and spatial data analyses were carried out. Land use categories of nine subdistricts providing in the GIS theme supported by Department of Land Development, Thailand. The land use themes were calculated by ArcGist 9.3. According to the themes, three main areas, including paddy field, fish farm and urban areas, were classified and analyzed in percentage unit for two periods (1994 and 2002). Relationships between the percentage of those land use areas in the years 1994 and 2002 were evaluated and compared by simple correlation.

\section{B. Local Questionnaire Survey}

A questionnaire addressing local bird species from the past to the present is designed. Interview to local people was done by using designed questionnaire. The target population was selected only the local people who lived in the area more than 20 years and farmers were focused. During the survey, bird pictures were important for validity to ensure the bird species precise identified. The results were analysed then stating bird situations from the past to the present.

\section{RESULTS}

\section{A. Land Use Change}

Paddy fields, fish farms and urban areas based on the interpretation of GIS themes in each subdistrict illustrated in Table II. Results showed the change of paddy fields, fish farms and urban areas in two periods. From 1994 to 2002, paddy fields decreased throughout the areas by the ranges of $0.79 \%$ to $59.97 \%$ while fish farms increased at a similar rate of $9.95 \%-54.06 \%$. Urban area slightly increased around $1.08 \%-15.57 \%$ and only Bangkaew dramatically increased by $33.15 \%$. The pattern of change from paddy fields to fish farms in a similar rate was happen in all three subdistricts of Bangsaothong whereas there were some different in Bangpli area, including Bangpliyai, Rachathewa, Bangsaothong, Srisajorakhenoi and Srisajorakheyai. However, those increasing patterns were not happen in Bangpla and Bangpliyai and Srisajorakhenoi.

TABLE II: PADDY FIELD, FISH FARM AND URBAN DEVELOPMENT IN 1994 AND 2002

\begin{tabular}{|c|c|c|c|c|c|c|c|c|c|}
\hline \multirow{2}{*}{$\begin{array}{c}\text { Land use } \\
\text { Subdistricts }\end{array}$} & \multicolumn{4}{|c|}{ Paddy fields } & \multicolumn{2}{|c|}{ Fish farms } & \multicolumn{3}{|c|}{ Urban development } \\
\hline & 1994 & 2002 & $\begin{array}{c}\text { Change } \\
(\%)\end{array}$ & 1994 & 2002 & $\begin{array}{c}\text { Change } \\
(\%)\end{array}$ & 1994 & 2002 & $\begin{array}{c}\text { Change } \\
(\%)\end{array}$ \\
\hline Bangpliyai & 13.34 & - & -13.34 & 65.33 & 83.43 & 18.10 & 19.12 & 14.70 & -4.42 \\
\hline Bangkaew & 33.93 & - & -33.93 & 23.34 & 19.08 & 16.74 & 47.69 & 80.84 & 33.15 \\
\hline Bangpla & 0.79 & - & -0.79 & 94.89 & 84.25 & -10.63 & 2.97 & 15.18 & 12.21 \\
\hline Rachatewa & 35.02 & - & -35.02 & 43.97 & 68.28 & 24.31 & 18.61 & 28.68 & 10.07 \\
\hline Nongpru & 41.59 & - & -41.59 & 54.29 & 80.32 & 26.03 & 4.07 & 19.64 & 15.57 \\
\hline Bangsaothong & 43.19 & 5.05 & -38.14 & 43.24 & 83.47 & 40.23 & 8.09 & 9.17 & 1.08 \\
\hline Srisajorakhenoi & 53.96 & 0.50 & -53.45 & 42.62 & 96.63 & 54.01 & 3.29 & 1.81 & -1.48 \\
\hline Srisajorakheyai & 66.86 & 6.89 & -59.97 & 21.78 & 75.84 & 54.06 & 9.83 & 13.72 & 3.89 \\
\hline
\end{tabular}

TABLE III: THE NUMBER OF BIRD SPECIES IN EACH BEHAVIOR

\begin{tabular}{|l|l|l|l|l|}
\hline & $\begin{array}{l}\text { Disappearance } \\
\text { species }\end{array}$ & $\begin{array}{l}\text { Species } \\
\text { appearance }\end{array}$ & $\begin{array}{l}\text { Species } \\
\text { increase }\end{array}$ & $\begin{array}{l}\text { Species } \\
\text { decrease }\end{array}$ \\
\hline Bangpliyai & 4 & 48 & 3 & 6 \\
\hline Bangkaew & 25 & 62 & 13 & 18 \\
\hline Bangpla & 6 & 53 & 5 & 9 \\
\hline Rachatewa & 9 & 26 & 4 & 6 \\
\hline Nongpru & 15 & 56 & 10 & 1 \\
\hline Bangchalong & 13 & 39 & 2 & 4 \\
\hline Bangsaothong & 13 & 59 & 3 & 14 \\
\hline Srisajorakhenoi & 15 & 67 & 9 & 15 \\
\hline Srisajorakheyai & 11 & 39 & 6 & 9 \\
\hline
\end{tabular}

Data from questionnaire survey insist the characteristics of land use change from paddy fields to fish farms. Many farmers provided the similar response for their points of view regarding agricultural behavior. Paddy fields require more budgets for farming practice whereas economic profit is less than fish farms. It is not surprising why those changes have been expanded.

The correlation coefficient showed a number of strong associations between pairs of farmland changed of the nine subdistricts. Paddy field declining was negative significantly correlated with fish farm expansion $(R=-0.915)$ (see Table VI). The result agreed with the data from Department of Land development, illustrated in Table I.

\section{B. Local Ecology}

The benefit to investigate local ecology by questionnaire interview to local people is that they can see the change of bird community from the past to the present. Comparing with the field survey, the period covered is advantage for questionnaire survey method. 
TABLE IV: BIRD SPECIES FOUND WITHIN THREE HABITAT TYPES

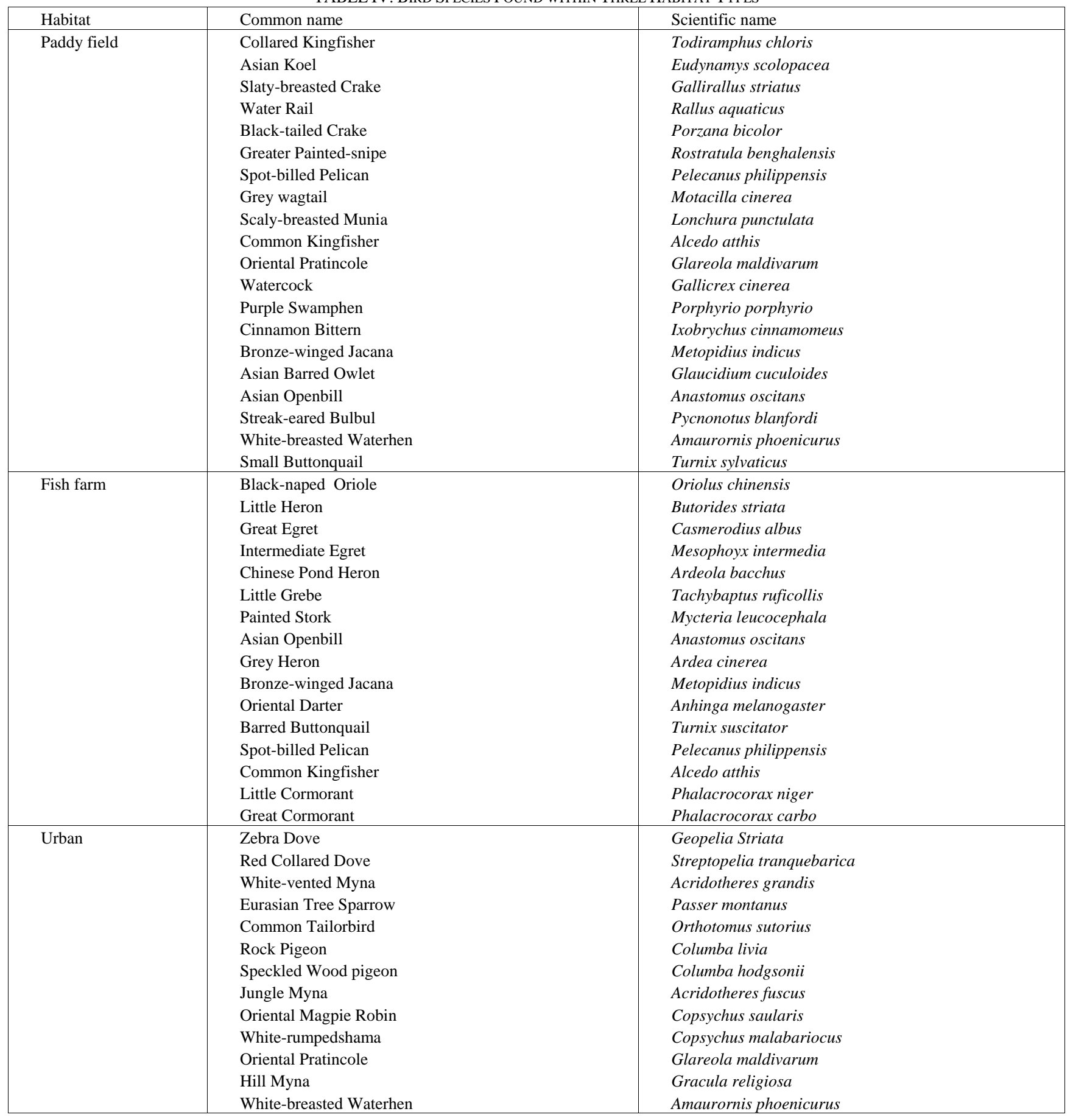

Result in Table III illustrated the change of bird species. Habitat changed from paddy fields to fish farms and urban development influences bird species patterns in both increment and falling-off whereas some species disappeared. The species which can adapt their living behavior in habitat heterogeneity were able to exist in fish farms situation and also for urban land use. These groups, for example Asean Openbill (Anastomus oscitans), Little Heron (Butorides striata), Great Egret (Casmerodius albus), have been continually increased their numbers. For disappearance groups, species disappeared was ranged from 6 to 25 depending on land utilization. Most of these species use paddy fields as their habitats in which are more complex than fish farm habitat. Moreover, the change of life style behavior was also found. That is, for example, the change from migration species to local species of Asean Openbill
(Anastomus oscitans), Brown-headed Gull (Larus brunnicephalus) and Black Drongo (Dicrurus macrocercus) which they normally immigrated only in winter season. Nowaday, they can be found in around the airport for all periods of the year. These groups create subsequent problem for Airport operation. For, urban living species were not affected by any change of land use.

Table IV illustrated bird taxa in each habitat types. Within these habitats, ecological indicators were further considered. They were then separated in issue interested, including species evenness, disappearance species and behavior changed species.

Among ecological indicators, species evenness is significant impacts which affect other ecological mechanism. It describes the number of individuals of each species in the same area. The study was found that land use alteration even 
different types of agricultural area could create the increasing or decreasing of individual number of some bird species. Those were noteworthy when land use was changed from paddy fields to fish farms. The individual number of increasing was higher and fifteen bird species were found. Usually, these were fish farm and urban habitats living species. These species were White-vented Myna (Acridotheres grandis), Common Myna (Acridotheres tristis), Rock Pigeon (Columba livia), Chinese Pond Heron (Ardeola bacchus), Great Egret (Casmerodius albus), Asian Openbill (Anastomus oscitans), Eurasian Tree Sparrow (Passer montanus), Great Cormorant (Phalacrocorax carbo), Little Cormorant (Phalacrocorax niger), Spotted Dove (Streptopelia chinensis), Baya Weaver (Ploceus philippinus), Common Tailorbird (Orthotomus sutorius), Zebra Dove (Geopelia Striata), Greater Coucal (Centropus sinensis) and Lesser Coucal (Centropus bengalensis).

On contrary, the decreasing of individual species was at ten bird species. The paddy field bird habitat species were totally declined their numbers when the less complex of fish farm habitat were replaced. These were included Indian Roller (Coracias benghalensis), Green Bee-eater (Merops orientalis), White-browed Crake (Porzana cinerea), Baillon's Crake (Porzana pusilla), Asian Barred Owlet (Glaucidium cuculoides), Asian Koel (Eudynamys scolopacea), Red-whiskered Bulbul (Pycnonotus jocosus), Streak-eared Bulbul (Pycnonotus blanfordi), Oriental Magpie Robin (Copsychus saularis) and Purple Heron (Ardea purpurea). Although the number of individual species was increased, the less species diversity was also paralleled.

For species disappearance, they were mostly found in paddy field used habitat. Unluckily, these species groups significantly showed the highest number with thirty species. The important species of this group were in Accipitridae family, for example, Black Kite (Milvus migrans), Brahminy Kite (Haliastur Indus), Oriental Honey-buzzard ( Pernis ptilorhyncus), Shikra (Accipiter badius) and Northern Goshawk (Accipiter gentilis). The others were Streak-eared Bulbul (Pycnonotus blanfordi), Forest Wagtail( Dendronanthus indicus), Paddyfield Pipit( Dendronanthus indicus), Fulvous-breasted Woodpecker (Dendrocopos macei), White-browed Piculet( Sasia ochracea), Watercock (Gallicrex cinerea), Black-collared Myna (Gracupica nigricollis), Barn Owl (Tyto alba), Black-crowned Night Heron (Nyctocorax nycticorax), Black-tailed Crake (Porzana bicolor), Slaty-breasted Crake (Gallirallus striatus), Purple Swamphen (Porphyrio porphyria), Greater Painted-snipe (Rostratula benghalensis), Red-wattled Lapwing (Vanellusindicus), Common Kingfisher (Alcedoatthis), Himalayan Griffon (himalayensis), Lineated Barbet Gyps( Megalaima lineate), Collared Scops Owl (Otus lempiji), Black-naped Oriole (Oriolus chinensis), Slender-billed Oriole (Oriolus tenuirostris), Scaly-breasted Munia (Lonchura punctulata), Large-billed Crow (Corvus macrohynchos), White-breasted Waterhen (Amaurornis phoenicurus), White-bellied (Haliaeetus leucogaster) and Sea Eagle Bronze-winged Jacana (Metopidius indicus).

As to behavior changed, the findings of study were found eight bird species. As mentioned above, migration behaviors are remarkable and these species were Brown-headed Gull (Larus brunnicephalus), Black Drongo (Dicrurus macrocercus), Slender-billed Oriole (Oriolu stenuirostris), Scaly-breasted Munia (Lonchura punctulata), Large-billed Crow (Corvus macrohynchos), White-breasted Waterhen (Amaurornis phoenicurus), White-bellied (Haliaeetus leucogaster) and Sea Eagle Bronze-winged Jacana (Metopidius indicus). Although they were found the least number, the impacts from themselves could reflect the need for land use sustainability.

TABLE V: PEARSON CORRELATION COEFFICIENT BETWEEN LAND USE AND

\begin{tabular}{|l|l|l|l|}
\hline \multicolumn{4}{|c}{ BIRD SPECIES } \\
\hline & Fish farm & Paddy field & Urban \\
\hline Fish farm & 1 & & \\
\hline Paddy field & $-0.915 * *$ & 1 & \\
\hline Urban & -0.456 & 0.113 & 1 \\
\hline General species & -0.078 & 0.137 & 0.104 \\
\hline Disappearance species & -0.034 & -0.227 & 0.776 \\
\hline Fish farm species & 0.254 & -0.192 & -0.116 \\
\hline Paddy field species & 0.017 & -0.086 & 0.521 \\
\hline \\
$* *$ correlation is significant at the 0.05 level \\
* correlation is significant at the 0.01 level \\
\hline
\end{tabular}

Pearson correlation coefficient in Table V and Stepwise multiple linear regression in Table VI were performed to confirm the relation between land use types and groups of bird species. The increasing of fish farms was significant found in opposite direction with the decreasing of paddy fields, by high statistical association $(p<0.01)$. Land use of urban area was also correlated $(p<0.05)$ with species disappearance. Table VI illustrated the development of equation model, performed by Stepwise multiple linear regression. It showed some characteristics of bird species behaviors with different land use. Regression model explained the greatest variation in the amount of urban expansion and the disappearance of bird accounted for $60.2 \%$ (Model 2 in Table VI). The contribution of fish farm land use and disappearance species in Model $3\left(R^{2}=0.001\right)$ showed the smallest due to the negative correlation in Table $\mathrm{V}$. The result was not different for paddy field and disappearance species in Model $6\left(R^{2}=0.051\right)$ in which negative association was found. Therefore the variance explained by this study model is significant for disappearance species and urban area.

TABLE VI: MULTIPLE LINEAR REGRESSION OF LAND USE AND BIRD SPECIES

\begin{tabular}{|c|l|c|}
\hline Model & \multicolumn{1}{|c|}{ Equation model } & $R^{2}$ \\
\hline 1 & \multicolumn{1}{|c|}{ General species $=64.76+0.261$ urban area } & 0.030 \\
\hline 2 & Disappearance species $=5.106+0.673$ urban area & 0.602 \\
\hline 3 & Disappearance species $=11.857-0.016$ fish farm & 0.001 \\
\hline 4 & Fish farm species $=18.578+0.068$ fish farm & 0.064 \\
\hline 5 & Paddy field species $=6.504-0.038$ paddy field & 0.007 \\
\hline 6 & Disappearance bird species $=7.330-0.122$ paddy field & 0.051 \\
\hline
\end{tabular}

\section{CONCLUSION}

The results of this research illustrate the view point of ecological change affecting from civilization demand. One of the most corresponding ways is that species diversity in paddy fields is clearly more than in fish farms. The increasing of fish farm species, such as Asian Openbill (Anastomus oscitans), Little Grebe (Tachybaptus ruficollis) and Great 
Egret (Casmerodius albus), and urban habitat species, such as Rock Pigeon (Columba livia) and Eurasian Tree Sparrow (Passer montanus), together with dominant species, Asian Openbill (Anastomus oscitans) and again Rock Pigeon (Columba livia), were consistent.

Agricultural development has been proceeded in many areas. Hara et al. (2005) remarked that the shifting from paddy fields to urban land use directly affect the loss of flood water retention areas [9]. This physical impact is emerged in this study. However, the biological impacts which may be unseen, especially the change of ecological pattern, are one of some hiddenness.

\section{ACKNOWLEDGMENT}

This research has been fund by Office of the Commission for Higher Education and Thailand Research Fund. The author would also like to thanks Faculty of Science, Silpakorn University to support all sufficient facilities.

\section{REFERENCES}

[1] K. A. Chapman and P. B. Reich, "Land use and habitat gradient determine bird community diversity and abundance in suburban, rural and reserve landscape of Minnesota, USA," Biological Conservation, vol. 135, pp. 527-541, April 2014.

[2] C. Sirami, L. Brotons, I. Burfield, J. Fonderflick, and J. L. Martin, "Is land abandonment having an Impact on biodiversity? A meta-analysis approach to bird distribution changes in the North-Western Mediterranean," Biological Conservation, vol. 141, pp. 450-459, December 2013

[3] L. Head, K. Parker, L. A. Chisholm, and N. Feneley, "A conceptual model of ecological connectivity in the Shell harbour local government area, New South Wales, Australia," Landscape and Urban Planning, vol. 86, pp. 47-59, December 2013.

[4] P. Rossi, A. Pecci, V. Amadio, O. Rossi, and L. Soliani, "Coupling indicators of ecological value and ecological sensitivity with indicators of demographic pressure in the demarcation of new areas to be protected: The case of the Oltrepo Pavese and the Ligurian-Emilian Apennine area (Italy)," Landscape and Urban Planning, vol. 85, pp 12-26, January 2014

[5] P. Opdam, J. W. Termorshuizen, and A. V. D. Brink. (January 2014) Incorporating ecological sustainability into landscape planning Landscape and Urban Planning. [Online]. 84, pp. 72-85. Available: http://www.journals.elsevier.com/landscape-urban-planning

[6] A. Nejadi, H. R. Jafari, M. F. Makhdoum, and M. Mahmoud, "Modeling plausible impacts of land use change on wildlife habitats, application and validation: Lisar protected area, Iran," Int. J. Environ. Res., vol. 6, vo. 4, pp. 883-892, May 2014.

[7] I. F. Spellerberg, Monitoring Ecological Change, $1^{\text {st }}$ ed. New York: Cambridge University Press, 2005, ch. 2.

[8] Department of Land Development, Land Use of Samutprakarn, Ministry of Agriculture, Thailand, 2014.

[9] Y. Hara, K. Takeuchi, and S. Okubo. (2005). Urbanization linked with past agricultural landuse patterns in the urban fringe of a deltaic Asian mega-city: a case study in Bangkok. Landscape and Urban Planning. [Online]. 73, pp. 16-28. Available: http://www.journals.elsevier.com/landscape-urban-planning

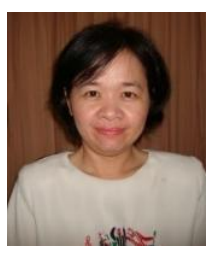

Kanokporn Swangjang was born in Bangkok, Thailand. She graduated with the $\mathrm{PhD}$ degree in environmental impact assessment from EIA Unit, Aberystwyth University, United Kingdom in 2000. She has been worked at the Department of Environmenta Science, Faculty of Science, Nakorn Pathom, Thailand, since 1992 and her current position is associated professor.

At present, she held the position as the president of Thai Society of Higher Education Institutes on Environment, TSHE. Her research interest is in the field of environmental assessment. 